\title{
Erratum
}

\section{A Critical Analysis of Conditionalities in the Generalized System of Preferences - ERRATUM}

\author{
Une analyse critique des conditionnalités dans le \\ système généralisé de préférences — ERRATUM
}

\section{PALLAVI KISHORE}

https://doi.org/10.1017/cyl.2017.8, Published by Cambridge University Press, 18 July 2017 .

The footnote containing the author's affiliation was mistakenly omitted from the published version of the article by Kishore. ${ }^{1}$ The author's information should appear as follows:

Pallavi Kishore, Associate Professor and Assistant Director, Centre for International Trade and Economic Laws, Jindal Global Law School, OP Jindal Global University, Sonipat, India.

The editors regret this error and apologize to the author and readers.

${ }^{1}$ Pallavi Kishore, "A Critical Analysis of Conditionalities in the Generalized System of Preferences” (2016) 54 Can YB Intl L 98. 